\title{
The effect of ferulic acid ethyl ester on leptin-induced proliferation and migration of aortic smooth muscle cells
}

\author{
Yung-Chieh Tsai ${ }^{1,2,3}$, Yen-Mei Lee ${ }^{4}$, Chih-Hsiung Hsu ${ }^{5}$, Sy-Ying Leu ${ }^{6}$, Hsiao-Yen Chiang ${ }^{7}$, Mao-Hsiung Yen ${ }^{4}$ \\ and Pao-Yun Cheng ${ }^{8}$
}

Leptin is a peptide hormone, which has a central role in the regulation of body weight; it also exerts many potentially atherogenic effects. Ferulic acid ethyl ester (FAEE) has been approved for antioxidant properties. The aim of this study was to investigate whether FAEE can inhibit the atherogenic effects of leptin and the possible molecular mechanism of its action. Both of cell proliferation and migration were measured when the aortic smooth muscle cell (A10 cell) treated with leptin and/or FAEE. Phosphorylated p44/42MAPK, cell cycle-regulatory protein (for example, cyclin D1, p21, p27), $\beta$-catenin and matrix metalloproteinase-9 (MMP-9) proteins levels were also measured. Results demonstrated that leptin $\left(10,100 \mathrm{ng} \mathrm{ml}^{-1}\right.$ ) significantly increased the proliferation of cells and the phosphorylation of p44/42MAPK in A10 cells. The proliferative effect of leptin was significantly reduced by the pretreatment of U0126 $(0.5 \mu \mathrm{M})$, a MEK inhibitor, in A10 cells. Meanwhile, leptin significantly increased the protein expression of cyclin D1, p21, $\beta$-catenin and decreased the expression of p27 in A10 cells. In addition, leptin $\left(10 \mathrm{ng} \mathrm{ml}^{-1}\right)$ significantly increased the migration of A10 cells and the expression of MMP-9 protein. Above effects of leptin were significantly reduced by the pretreatment of FAEE ( 1 and $10 \mu \mathrm{m})$ in A10 cells. In conclusion, FAEE exerts multiple effects on leptin-induced cell proliferation and migration, including the inhibition of p44/42MAPK phosphorylation, cell cycle-regulatory proteins and MMP-9, thereby suggesting that FAEE may be a possible therapeutic approach to the inhibition of obese vascular disease.

Experimental \& Molecular Medicine (2015) 47, e180; doi:10.1038/emm.2015.56; published online 28 August 2015

\section{INTRODUCTION}

The pathogenesis of artery disease and its complications is multifactorial, involving vasoconstriction, thromboembolism and vascular smooth muscle cell proliferation. ${ }^{1}$ Risk factors such as aging, obesity, diabetes mellitus and dyslipidemia adversely regulate the disease process. ${ }^{2,3}$ Leptin, the obesity gene $(o b)$ product, participates in the control of body weight by regulating food intake and energy expenditure. ${ }^{4,5}$ Several studies have shown an independent interaction between high leptin and atherosclerosis, myocardial infarction, stroke and coronary artery intima-media thickness, suggesting that high levels of leptin may increase cardiovascular risk. ${ }^{6-8}$ Leptin acts through the leptin receptors, which are expressed in atherosclerotic plaque, injured neointima and the media and are found in vascular smooth muscle cells. ${ }^{9}$ Leptin can promote processes involved in atherogenesis, including platelet aggregation, inflammation, endothelial dysfunction and vascular smooth muscle cells proliferation and migration. ${ }^{6}$

Ferulic acid (4-hydroxy-3-methoxycinnamic acid; FA) is a phenolic compound largely present in plants and also in vegetable foods, such as olives and olive oil. It has been shown to possess some scavenging activity toward hydroxyl radical, peroxynitrite and oxidized low-density lipoprotein in vitro. ${ }^{10-12}$ Ferulic acid ethyl ester (ethyl 4-hydroxy-3- methoxycinnamate; FAEE) is the ethyl ester, derivative of FA. The ester group of FAEE makes the compound more lipophilic when compared with FA. ${ }^{13}$ FAEE has been shown to have both antiinflammatory and antioxidant properties as stated above for

\footnotetext{
${ }^{1}$ Department of Obstetrics and Gynecology, Chi-Mei Medical Center, Tainan, Taiwan; ${ }^{2}$ Department of Medicine, Taipei Medical University, Taipei, Taiwan; ${ }^{3}$ Department of Sport Management, Chia Nan University of Pharmacy and Science, Tainan, Taiwan; ${ }^{4}$ Department of Pharmacology, National Defense Medical Center, Taipei, Taiwan; ${ }^{5}$ Department of Internal Medicine, Tri-Service General Hospital, National Defense Medical Center, Taipei, Taiwan; ${ }^{6}$ Graduate Institute of Life Sciences, National Defense Medical Center, Taipei, Taiwan; ${ }^{7}$ Department of Chinese Pharmaceutical Sciences and Chinese Medicine Resources, China Medical University, Taichung, Taiwan and ${ }^{8}$ Department of Physiology and Biophysics; Graduate Institute of Physiology, National Defense Medical Center, Taipei, Taiwan

Correspondence: Dr P-Y Cheng, Department of Physiology and Biophysics; Graduate Institute of Physiology, National Defense Medical Center, No. 161, Sec 6, Min-Chuan East Road, Taipei 114, Taiwan.

E-mail: pycheng@mail.ndmctsgh.edu.tw
}

Received 7 January 2015; revised 24 May 2015; accepted 27 May 2015 
FA. ${ }^{10,11,14}$ Reactive oxygen species have been proposed to be important signaling molecules in many biological events such as cell proliferation, which is important in the pathogenesis of intimal thickening in atherosclerosis and restenosis. ${ }^{15,16}$ Based on the mechanisms by which FAEE scavenges free radicals, the aim of the present study was to investigate the ability of FAEE to provide anti-atherosclerostic effect against leptin-induced smooth muscle cell proliferation and migration.

\section{MATERIALS AND METHODS}

\section{Cell culture}

Rat aortic smooth muscle A10 cells (derived from the American Type Culture Collection) purchased from the Food Industry Research and Development Institute, Hsinchu, Taiwan and were cultured in Dulbecco's Modified Eagle's medium (DMEM) (Gibco Life Technologies, Grand Island, NY, USA) supplemented with $10 \%$ fetal bovine serum (Gibco Life Technologies) at $37^{\circ} \mathrm{C}$ in a humidified atmosphere of $5 \% \mathrm{CO}_{2}$. The cell were fed every 2-3 days and subcultured once they reached $90-100 \%$ confluence.

\section{Cell proliferation assay}

The cell proliferation assay was performed using the CellTiter 96 AQueous One Solution kit (Promega, Madison, WI, USA). In brief, cells were seeded at a concentration of $4 \times 10^{3}$ cells per well in 96-well plates. After cell attachment, the medium was replaced with DMEM containing $2 \%$ fetal bovine serum. After incubated in 2\% fetal bovine serum DMEM for $48 \mathrm{~h}$, cells were exposed to variable concentrations (1-100 $\mathrm{ng} \mathrm{ml}^{-1}$ ) of leptin (R\&D Systems, Inc., Minneapolis, MN, USA) for another $72 \mathrm{~h}$, respectively. Cells were treated with leptin alone or/and pretreated with FAEE (Sigma-Aldrich, St Louis, MO, USA) for $1 \mathrm{~h}$. Relative cell numbers were investigated by incubating cells with $20 \mu \mathrm{l}$ CellTiter 96 AQueous One Solution Reagent for $4 \mathrm{~h}$ at $37^{\circ} \mathrm{C}$ and then record the absorbance at $490 \mathrm{~nm}$ using a 96-well plate reader.

\section{BrdU incorporation assay}

The proliferation of cells was measured by DNA synthesis using bromodeoxyuridine (BrdU) proliferation assay kit according to the manufacturer's instructions (Cell Signaling Technology, Danvers, MA, USA). In brief, quiescent cells were pretreated with or without FAEE for $1 \mathrm{~h}$ prior to stimulation with leptin $\left(1-100 \mathrm{ng} \mathrm{m}^{-1}\right)$ for $72 \mathrm{~h}$. Subsequently, $10 \mu \mathrm{M}$ BrdU was added to the cells and incubated for another $24 \mathrm{~h}$. The BrdU-labeled DNA has to be denatured to be detected by the BrdU mouse monoclonal antibody used in this kit and followed by incubation with the horseradish peroxidase-conjugated secondary antibody. The immune complex was detected following the addition of horseradish peroxidase substrate TMB and measured at $450 \mathrm{~nm}$ using an enzyme-linked immunosorbent assay reader. The number of proliferating cells is represented by the level of BrdU incorporation, which directly correlates to the color intensity and the absorbance values. Cell proliferation was expressed as the percentage of BrdU incorporation.

\section{$\mathrm{LDH}$ release assay}

Lactate dehydrogenase $(\mathrm{LDH})$ release was determined using a $\mathrm{LDH}$ cytotoxicity assay kit (BioChain, Thurmont, MD, USA) according to the manufacturer's instructions. Cells $\left(2 \times 10^{4}\right.$ cells per well $)$ were plated in 24-well plate with $500 \mu \mathrm{l}$ of DMEM overnight before FAEE treatment. After different doses of FAEE treatment for $24 \mathrm{~h}$, the medium from each well was collected to measure the amount of released LDH. Cells in adjacent wells were exposed to lysis buffer, and the medium was collected to measure the amount of total cellular $\mathrm{LDH}$. The amount of LDH from each sample was measured at $490 \mathrm{~nm}$ by the microplate reader. The percentage of released LDH vs total cellular LDH was calculated as the LDH leaking ratio.

\section{Cell migration assay}

Cell migration was examined using Transwell Permeable Support Culture Plate System (Corning Inc., Corning, NY, USA). Growtharrested cells were harvested, washed and resuspended in the media $\left(\mathrm{DMEM}+0.1 \%\right.$ fetal bovine serum). Approximately $1 \times 10^{5}$ cells were placed in the upper chamber of a 24-well transwell. FAEE (1 and $10 \mu \mathrm{M}$ ) was added to both the upper and the lower compartments and was present throughout the duration of the experiment. Migration was induced by the addition of leptin $\left(10 \mathrm{ng} \mathrm{ml}^{-1}\right)$ to the lower chamber. After incubation at $37^{\circ} \mathrm{C}$ for $48 \mathrm{~h}$, the non-migratory cells were removed from the upper surface of the membrane by scraping them with cotton swabs. The membrane was fixed with $90 \%$ ethanol and stained with $0.1 \%$ crystal. Migrated cells were counted at $\times 200$ magnification in five randomly chosen microscope fields per filter. The values obtained were calculated by averaging the total number of cells from five filters and the migration index indicated the fold value of cell migration.

\section{Western blot analysis}

Samples containing equal amounts of protein were loaded onto $10 \%$ sodium dodecyl sulfate-polyacrylamide gels, subjected to electrophoresis and subsequently blotted onto nitrocellulose membrane (Millipore, Bedford, MA, USA). Membranes were blocked with tris-buffered saline buffer, pH 7.4, containing $0.1 \%$ Tween 20 and 5\% skim milk and then incubated overnight at $4{ }^{\circ} \mathrm{C}$ with various primary antibodies in tris-buffered saline containing $0.1 \%$ Tween 20 . The antibodies included mouse anti-p21 (1:2000 dilution, Santa Cruz Biotechnology, Dallas, TX, USA), mouse anti- $\beta$-actin (1:2000 dilution; SigmaAldrich), rabbit anti-cyclin D1 (1:2000 dilution, Santa Cruz Biotechnology), rabbit anti-phosphorylated p44/42MAPK (1:1000 dilution; Cell Signaling Technology), rabbit anti-p27 (1:1000 dilution; Cell Signaling), rabbit anti- $\beta$-catenin (1:1000 dilution; Cell Signaling) and rabbit anti-MMP-9 (1:1000 dilution; Millipore, Temecula, CA, USA). The membranes were incubated with horseradish peroxidaseconjugated secondary antibodies (1:1000 dilution; Cell Signaling). The blots were detected with an enhanced chemiluminescence kit (Pierce, Rockford, IL, USA) and a bio-imaging analyzer (Fujifilm LAS-4000). The density of the respective bands was quantified by densitometric scanning of the blots using Image-Pro software (Media Cybermetrics, Inc., Bethesda, MD, USA).

\section{Gelatin zymography}

Gelatinase activity in conditioned medium collected from cell cultures was measured with zymography. Conditioned medium were electrophoresed on a Novex 10\% gelatin zymogram gel (Invitrogen, Life technologies, Carlsbad, CA, USA). After electrophoresis, the gel was incubated at room temperature for $30 \mathrm{~min}$ with renaturing buffer (Invitrogen) and placed overnight in developing buffer (Invitrogen). The gel was stained with SimplyBlue SafeStain (Invitrogen) for $1 \mathrm{~h}$ and destained in deionized water. Clear zones against a blue background indicated the presence of gelatinolytic activity. 
Statistical analysis

All measurements are expressed as means \pm standard errors. Statistical evaluation was performed with one-way analysis of variance (ANOVA) followed by the Newman-Keuls method. A $P$-value of $<0.05$ was deemed statistically significant.

\section{RESULTS}

FAEE inhibited leptin-stimulated A10 cell proliferation First, A10 cells were cultured in medium supplemented with leptin $\left(1,10\right.$ and $\left.100 \mathrm{ng} \mathrm{ml}^{-1}\right)$ for $72 \mathrm{~h}$. As shown in Figure 1a, the number of cells was significantly increased after stimulation with leptin in a concentration-dependent manner. Maximal effect was observed after $72 \mathrm{~h}$ at a concentration of $10 \mathrm{ng} \mathrm{ml}^{-1}$ leptin. Therefore, the $10 \mathrm{ng} \mathrm{ml}^{-1}$ concentration of leptin was selected for further studies. The concentrations used for FAEE $(1 \sim 50 \mu \mathrm{M})$ did not exhibit cytotoxic effects on cell viability (Figure 1b). The absence of cytotoxicity was further confirmed with a LDH cytotoxicity assay (Figure 1c). As shown in Figure 1d, proliferation of A10 cell incubated with leptin $\left(10 \mathrm{ng} \mathrm{ml}^{-1}\right)$ was significantly attenuated in the presence of FAEE $(1$ and $10 \mu \mathrm{M} ; P<0.05)$ and suggesting that FAEE has a potential antiproliferative effect on A10 cells stimulated by leptin. We further examined the effect of FAEE or $\mathrm{N}$-acetylcysteine $(5-10 \mu \mathrm{M})$, a free radical scavenger, on DNA synthesis, as induced by leptin in A10 cells using the BrdU incorporation assay. BrdU incorporation was markedly increased in A10 cells exposed to leptin $\left(1-100 \mathrm{ng} \mathrm{ml}^{-1}\right)$ for $72 \mathrm{~h}$, indicating an increase in DNA synthesis. However, this effect was attenuated in A10 cells pretreated with FAEE $(10 \mu \mathrm{M} ; P<0.05)$ or $\mathrm{N}$-acetylcysteine (5 and $10 \mu \mathrm{m} ; \mathrm{P}<0.05$ ) (Figure 1e).

The antiproliferative effect of FAEE was induced by p44/42MAPK suppression

It is well known that p44/42MAPK activation has an important role in cell proliferation. To confirm leptin-induced p44/42MAPK phosphorylation, we examined the phosphorylation of p44/42MAPK protein in A10 cells exposed to leptin ( 1 and $10 \mathrm{ng} \mathrm{ml}^{-1}$ ) for $30 \mathrm{~min}$. As shown in Figure 2a, leptin significantly induced the phosphorylation of p44/42MAPK in a concentration-dependent manner $(P<0.05)$, with a maximal effect at $10 \mathrm{ng} \mathrm{ml}^{-1}$. In addition, the effect of FAEE on leptininduced p44/42MAPK phosphorylation was investigated. The cells were stimulated with leptin $\left(10 \mathrm{ng} \mathrm{ml}^{-1}\right)$ for $30 \mathrm{~min}$ in the presence of FAEE ( 1 and $10 \mu \mathrm{M}$ ). As shown in Figure $2 \mathrm{~b}$, FAEE
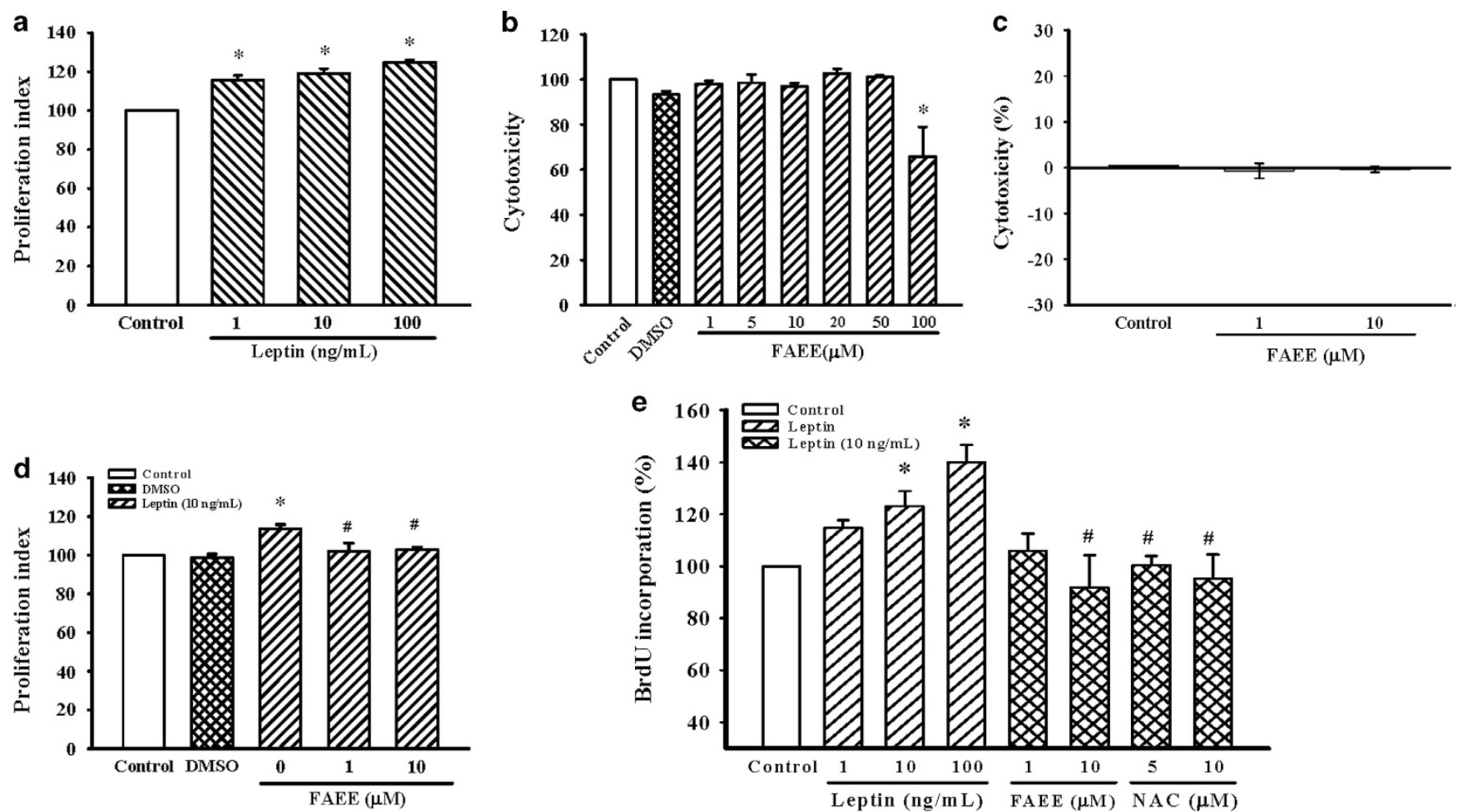

Figure 1 Effect of FAEE on leptin-induced proliferation of A10 cells. (a, d) Growth-arrested cells were stimulated with leptin (1-100 ng ml ${ }^{-1}$ ) for $72 \mathrm{~h}$ in the presence or absence of FAEE ( 1 and $10 \mu \mathrm{m}$ ). Cell proliferation was assayed by the CellTiter 96A Queous One Solution kit. Relative proliferation activities were expression using untreated control cells as a standard. Data represent as mean \pm s.e. of six independent observation with different cell passages and on different days. ${ }^{*} P<0.05$ vs control; ${ }^{\#} P<0.05$ vs leptin alone. (b, c) Cells were incubated with FAEE at increasing concentrations $(1-100 \mu \mathrm{m})$ for $24 \mathrm{~h}$; the toxic effects of FAEE were measure by the CellTiter $96 \mathrm{~A}$ Queous One Solution kit and LDH cytotoxicity assay kit, respectively. Data represent as mean \pm s.e. of six independent observation with different cell passages and on different days. ${ }^{*} P<0.05$ vs Control. (e) DNA synthesis was measured by BrdU incorporation assay. Growtharrested cells were stimulated with leptin $\left(1-100 \mathrm{ng} \mathrm{ml}^{-1}\right)$ for $72 \mathrm{~h}$ in the presence or absence of FAEE ( 1 and $\left.10 \mu \mathrm{m}\right)$ or NAC (5 and $10 \mu \mathrm{m})$. Data represent as mean \pm s.e. of six independent observation with different cell passages and on different days. ${ }^{*} P<0.05$ vs control; ${ }^{\#} P<0.05$ vs leptin alone. 
significantly attenuated the leptin-activated p44/42MAPK phosphorylation $(P<0.05)$. Next, A10 cells pretreated with MEK1/2 inhibitor U0126 $(0.5 \mu \mathrm{M})$ for $1 \mathrm{~h}$, and then stimulated with leptin $\left(10 \mathrm{ng} \mathrm{ml}^{-1}\right)$ for $72 \mathrm{~h}$. Leptin-stimulated A10 cell proliferation was decreased by MEK1/2 inhibitor (Figure 2c; $P<0.05)$.

Effect of FAEE on the cyclin D1 expression in A10 cells It is known that cyclins, cyclin-dependent kinases (CDKs) and their inhibitors regulate cell cycle progression. Changes in the expression of cyclin D1, for example, can either stop or promote cell proliferation. To clarify whether inhibition by
FAEE involves the regulation of cell cycle-related proteins, the effect of FAEE on the cyclin D1 protein expression were assayed. As shown in Figure 3a, leptin $\left(10 \mathrm{ng} \mathrm{ml}^{-1}\right)$ significantly increased the expression of cyclin D1 in a time-dependent manner, beginning after incubation for $3 \mathrm{~h}$ and reaching a maximum after $6 \mathrm{~h}(P<0.05)$. However, FAEE $(1$ and $10 \mu \mathrm{M})$ significantly decreased the level of cyclin D1 elevated by leptin (Figure 3b; $P<0.05$ ).

Effect of FAEE on the p27 and p21 expression in A10 cells The effects of FAEE on the expression of CDK inhibitors were further examined. The p27 protein level was rapidly a
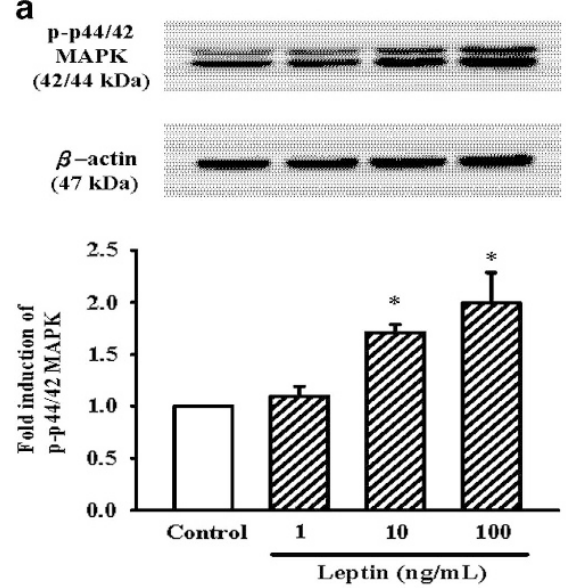

b
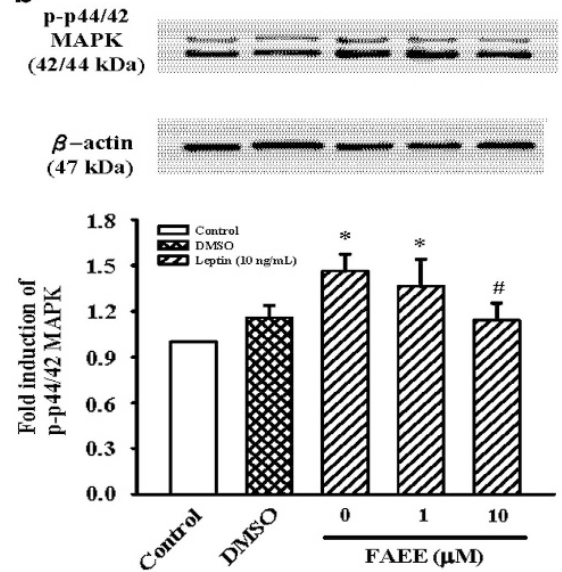

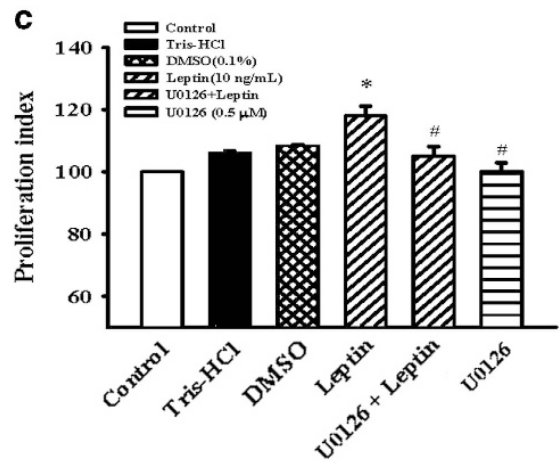

Figure 2 Effect of FAEE on leptin-induced p44/42MAPK phosphorylation in A10 cells. (a, b) Cells were stimulated with leptin (1-100 ng ml-1) for $30 \mathrm{~min}$ in the presence or absence of FAEE (1 and $10 \mu \mathrm{m})$. The cells were lysed and proteins were analyzed by western blotting. The $\beta$-actin was used for normalization. (c) Effect of MEK1/2 inhibitor (U0126) on the leptin-induced cell proliferation. Growtharrested cells were stimulated with leptin $\left(10 \mathrm{ng} \mathrm{m}^{-1}\right)$ for $72 \mathrm{~h}$ in the presence or absence of U0126 (0.5 $\left.\mu \mathrm{m}\right)$. Cell proliferation was assayed by the CellTiter 96A Queous One Solution kit. Relative proliferation activities were expression using untreated control cells as a standard. Data represent as mean \pm s.e. of four independent observation with different cell passages and on different days. ${ }^{*} P<0.05$ vs control; ${ }^{\#} P<0.05$ vs leptin alone.

a
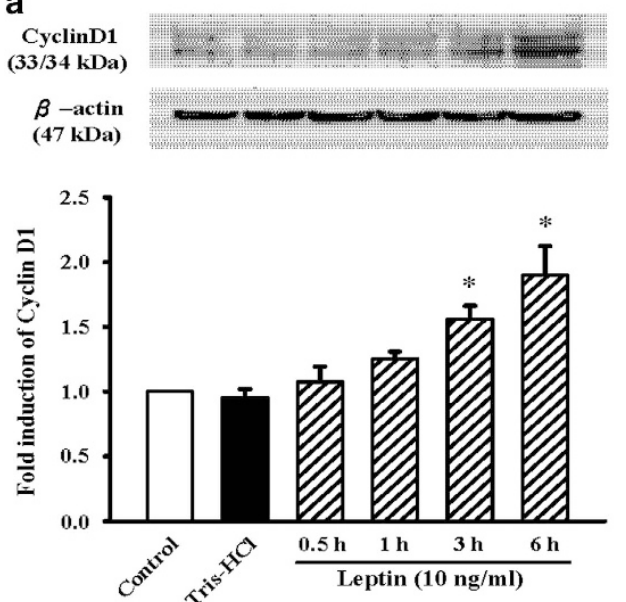

b
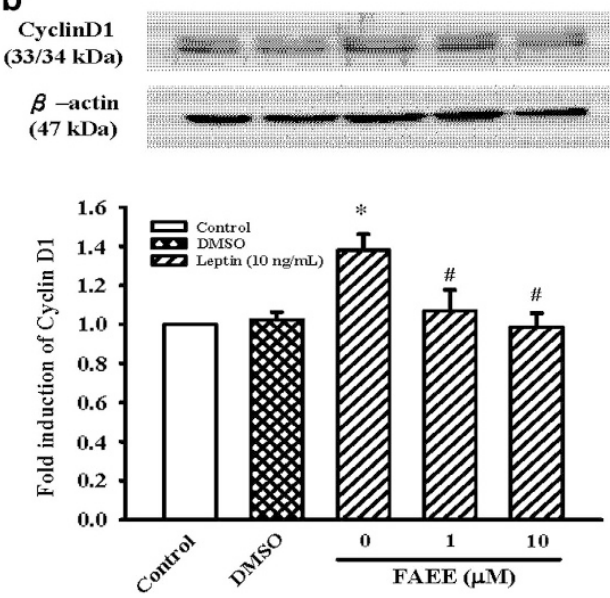

Figure 3 Effect of FAEE on leptin-induced cyclin D1 protein expression in A10 cells. (a) Cells were stimulated with leptin (10 ng ml ${ }^{-1}$ ) for $0.5-6 \mathrm{~h}$. (b) Cells were stimulated with leptin $\left(10 \mathrm{ng} \mathrm{ml}^{-1}\right)$ for $3 \mathrm{~h}$ in the presence or absence of FAEE ( 1 and $\left.10 \mu \mathrm{m}\right)$. The cells were lysed and proteins were analyzed by western blotting. The $\beta$-actin was used for normalization. Data represent as mean \pm s.e. of five independent observation with different cell passages and on different days. ${ }^{*} P<0.05$ vs control; ${ }^{\#} P<0.05$ vs leptin alone. 
downregulated by leptin $\left(10 \mathrm{ng} \mathrm{ml}^{-1}\right)$ stimulation for $3 \mathrm{~h}$ $(P<0.05)$, whereas the level of $\mathrm{p} 27$ protein was reversed and further increased by FAEE (1 and $10 \mu \mathrm{M})$ pretreatment (Figure 4a; $P<0.05$ ). In contrast, leptin lead to an increase in p21 expression after stimulation for $3 \mathrm{~h}$ in A10 cells. FAEE (1 and $10 \mu \mathrm{M}$ ) treatment significantly decreased the expression of p21 induced by leptin (Figure $4 \mathrm{~b} ; P<0.05$ ).

Effect of FAEE on the $\beta$-catenin expression in A10 cells It has been reported that $\beta$-catenin accumulation is a key step for its role in cell cycle control, proliferation and cell fate determination. ${ }^{17}$ The effects of FAEE on the expression of $\beta$-catenin were further examined. As shown in Figure 5a, the $\beta$-catenin protein level was rapidly upregulated by leptin (10 $\mathrm{ng} \mathrm{ml} l^{-1}$ ) stimulated after $3 \mathrm{~h}$, whereas the level of $\beta$-catenin protein was significantly attenuated by FAEE $(10 \mu \mathrm{M})$ pretreatment (Figure 5b).

FAEE inhibited leptin-induced migration of A10 cells As shown in Figure 6a, leptin significantly increase the A10 cells migration activity at $10 \mathrm{ng} \mathrm{ml}^{-1}$. Addition of FAEE (1 and
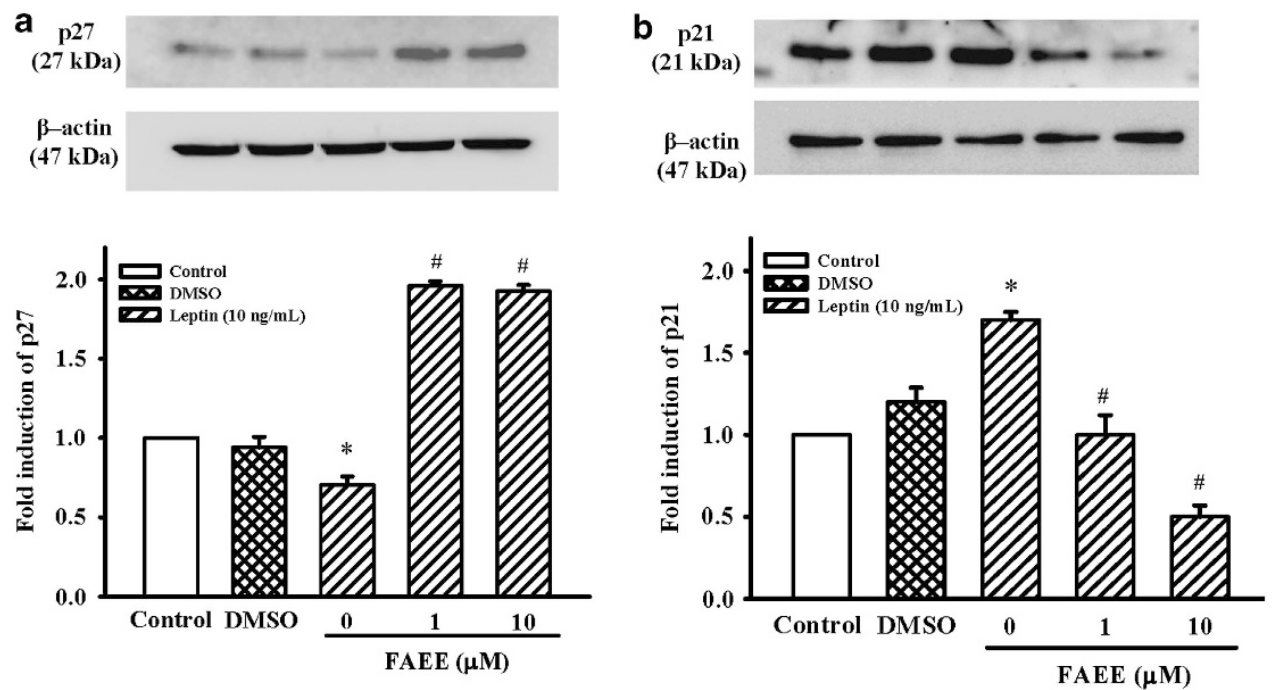

Figure 4 Effect of FAEE on leptin-induced P27 and p21 protein expression in A10 cells. (a, b) Cells were stimulated with leptin $\left(10 \mathrm{ng} \mathrm{ml}^{-1}\right)$ for $3 \mathrm{~h}$ in the presence or absence of FAEE (1 and $\left.10 \mu \mathrm{m}\right)$. The cells were lysed and proteins were analyzed by western blotting. The $\beta$-actin was used for normalization. After densitometric quantification, data represent as mean \pm s.e. of six independent observation with different cell passages and on different days. ${ }^{*} P<0.05$ vs control; ${ }^{\#} P<0.05$ vs leptin alone.
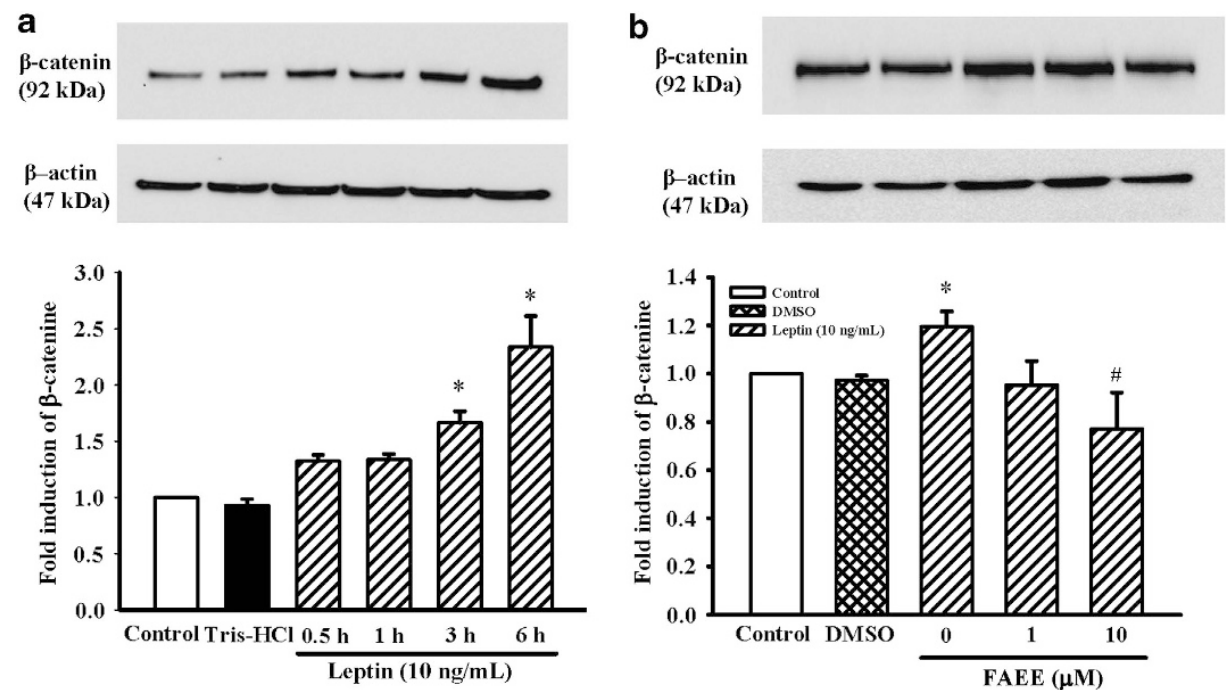

Figure 5 Effect of FAEE on leptin-induced $\beta$-catenin protein expression in A10 cells. (a) Cells were stimulated with leptin (10 ng ml ${ }^{-1}$ ) for 0.5-6 h. (b) Cells were stimulated with leptin $\left(10 \mathrm{ng} \mathrm{ml}^{-1}\right)$ for $3 \mathrm{~h}$ in the presence or absence of FAEE ( 1 and $\left.10 \mu \mathrm{m}\right)$. The cells were lysed and proteins were analyzed by western blotting. The $\beta$-actin was used for normalization. Data represent as mean \pm s.e. of six independent observation with different cell passages and on different days. ${ }^{*} P<0.05$ vs control; $\# P<0.05$ vs leptin alone. 
a
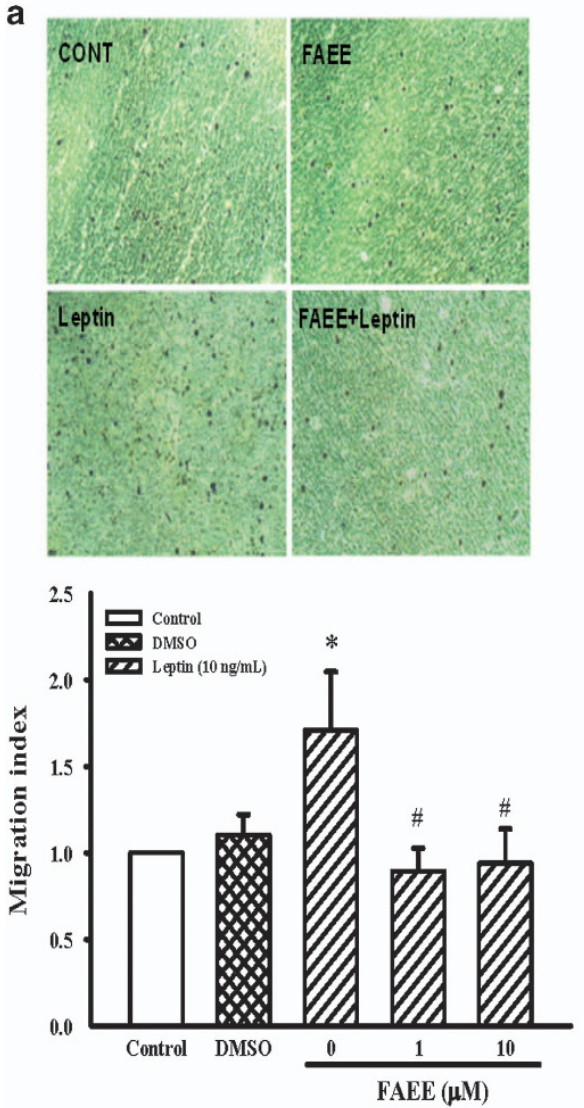

b

MMP-9

(92 kDa)

$\beta$-actin

(47 kDa)

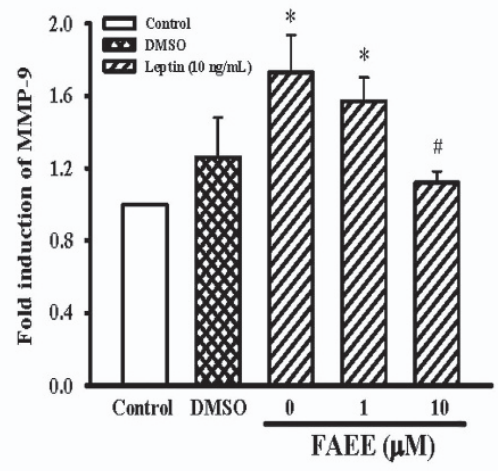

C

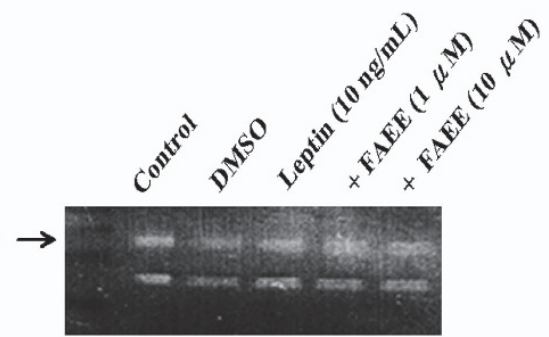

Figure 6 Effects of FAEE on leptin-induced VSMC migration as well as MMP-9 expression in A10 cells. (a) VSMCs migration was examined using Transwell Permeable Support Culture Plate System. After incubation at $37^{\circ} \mathrm{C}$ for $48 \mathrm{~h}$, migrated cells were counted at $\times 200$ magnification in five randomly chosen microscope fields per filter. Lower panel indicated the fold value of cell migration. Data represent as mean \pm s.e. of four independent observation with different cell passages and on different days. (b) Cells were stimulated with leptin $\left(10 \mathrm{ng} \mathrm{m}^{-1}\right)$ for $3 \mathrm{~h}$ in the presence or absence of FAEE ( 1 and $\left.10 \mu \mathrm{m}\right)$. The cells were lysed and MMP-9 protein was analyzed by western blotting. The $\beta$-actin was used for normalization. After densitometric quantification, data represent as mean \pm s.e. of five independent observation with different cell passages and on different days. ${ }^{*} P<0.05$ vs control; \#P<0.05 vs leptin alone. (c) Gelatin zymography analysis was performed with conditioned media collected from A10 cells cultured in the presence or absence of FAEE and leptin $\left(10 \mathrm{ng} \mathrm{ml}^{-1}\right)$.

$10 \mu \mathrm{M})$ significantly attenuated the migration activity of A10 cells induced by leptin (Figure 6a; $P<0.05$ ).

\section{Effect of FAEE on the expression of MMP-9 in A10 cells}

Vascular smooth muscle cell migration requires the breakdown of the extracellular matrix. It was reported that MMP-9 was important for the migration of vascular smooth muscle cell. The effect of FAEE on the expression of MMP-9 was further examined. As shown in Figure 6b, FAEE significantly attenuated the upregulation of MMP-9 protein expression induced by leptin $\left(10 \mathrm{ng} \mathrm{ml}^{-1}\right)$ in A10 cells $(P<0.05)$. The result of gelatin zymography also showed that, in a leptin culture medium, MMP-9 proteolytic activity was increased. FAEE pretreatment resulted in reduced in MMP-9 activity (Figure 6c).

\section{DISCUSSION}

This is a first study to demonstrate that FAEE inhibited the proliferative and migratory effects on aortic smooth muscle cells by leptin stimulation. To elucidate this mechanism, the effect of FAEE on p44/42MAPK phosphorylation as well as $\beta$-catenin, cyclin D1, p21 and p27 proteins expression were examined in A10 cells. In parallel, the effect of FAEE on leptininduced migration of A10 cell and the expression of MMP-9 were also investigated. Results demonstrated that the inhibition of FAEE on leptin-induced cell proliferation might be due to the downregulation of p44/42MAPK, $\beta$-catenin, cyclin D1 and p21 expression as well as the upregulation of p27 expression. Meanwhile, FAEE could inhibit A10 cells migration induced by leptin in associated with downregulation of MMP-9. These results suggest that FAEE may prove to be a potential therapeutic agent for the prevention, possibly, treatment of vascular diseases.

In mammals, the hormone leptin is physiologically secreted in response to increased body fat mass and acts at the hypothalamus to decrease appetite and increase energy expenditure. ${ }^{4}$ In humans, obesity, particularly abdominal obesity, is associated with high circulating leptin levels, which may be explained by hypothalamic leptin resistance. ${ }^{18,19}$ Leptin 
has been suggested to participate in vascular remodeling, as it induces the proliferation of rat vascular smooth muscle cells and promotes neointimal growth of vascular smooth muscle cells after injury in mice. ${ }^{20,21}$ Similar to these reports, in the present study leptin can induce the proliferation and migration of A10 cells in a concentration-dependent manner (Figure 1a and 6a). Meanwhile, FAEE potently inhibited this pattern of cells induced by leptin, and the antiproliferative effect of FAEE was not due to cytotoxicity (Figures $1 b$ and c). These results suggested that FAEE may have therapeutic effects in the prevention of atherosclerosis and neointimal hyperplasia.

The mitogen-activated protein kinase (MAPK)-mediated signal transduction pathway has been implicated in the control of vascular smooth muscle cells proliferation and migration. ${ }^{22}$ Activating p44/42MAPK is one of the major pathways for the regulation of proliferation and cell growth in various cultured cells. ${ }^{23}$ The present study had showed that phosphorylation of p44/42MAPK was significantly elevated when A10 cells exposure to leptin. Moreover, using specific inhibitors of MEK1/2 confirmed the involvement of p44/42MAPK in the cell proliferation induced by leptin (Figure 2c). This result was in agreement with other study that leptin stimulated vascular smooth muscle cells proliferation by p44/42MAPK activation. ${ }^{24}$ Furthermore, FAEE inhibited the leptin-induced p44/42MAPK activation, indicating that the $\mathrm{p} 44 / 42 \mathrm{MAPK}$ protein may be related to the antiproliferative activity of FAEE.

Cell cycle control is a highly regulated process that involves a complex cascade of events. Cyclin levels have been shown to be rate-limiting factors for G1 progression in mammalian cells, and many studies had showed that synthesis of cyclin D1 may be the target of physiological signals that control cell proliferation. ${ }^{25}$ To further investigate the antiproliferative effect of FAEE, cell cycle-regulatory proteins assay was performed. As shown in Figure 3, FAEE significantly inhibits the expression of cyclin D1 induced by leptin. In addition, the CDK inhibitors, p21 and p27, are important regulators of cyclin-CDK complexes. They can tightly bind and inhibit the kinase activities of several cyclin-CDK complexes and arrest cell growth. In the present study, FAEE prevented the downregulation of p27 after leptin stimulation (Figure 4a). This result agreed with other study that had showed upregulation of p27 expression exhibit antiproliferative effect in vascular smooth muscle cells. ${ }^{26}$ The present study had also showed that FAEE upregulated p27 expression is consistent with its inhibitory effect on cyclin D1 (Figure 3). Taken together, these data suggested that FAEE reduced A10 cells proliferation by blocking cell cycle progression. It is noteworthy that $\mathrm{p} 21$ acting via its assembly factor role is inhibiting the effect of cyclin D1 on its downstream effectors. ${ }^{27}$ However, in the present study, the expression of p21 was elevated after leptin stimulation; it was correlated with the cell proliferation induced by leptin in A10 cells. FAEE treatment attenuated the expression of p21 elevated by leptin stimulation (Figure $4 \mathrm{~b}$ ). This may be explained by the fact that p21 could function as a positive regulator of cell cycle. ${ }^{28,29}$ In addition to the function in the cell cycle, p21 has also been suggested to have a role in enhancing cell survival. ${ }^{30}$ Further studies are needed to clarify the mechanism via which leptin regulates the expression of $\mathrm{p} 21$.

The canonical Wnt/ $\beta$-catenin signaling pathway controls many cellular processes including proliferation and differentiation. ${ }^{31} \beta$-catenin activation and cell proliferation have been linked in arterial and vascular smooth muscle cells in vitro and in vivo after balloon injury of the rat carotid artery. ${ }^{32,33}$ A number of $\beta$-catenin target genes had been identified. Among them, cyclin D1 is an important protein that has a key role in cell cycle control and cell proliferation. ${ }^{34,35}$ In this study, the expression of $\beta$-catenin was upregulated by the stimulation of leptin, and the level of $\beta$-catenin was attenuated by the pretreatment of FAEE (Figure 5). Meanwhile, leptin-upregulated $\beta$-catenin expression is consistent with its enhanced action on cyclin D1 (Figure 3). Taken together, these finding further corroborated that FAEE reduced cells proliferation by blocking cell cycle progression. In addition, $\beta$-catenin protein is the primary substrate of GSK-3 $\beta$. GSK-3 $\beta$ can be negatively regulated by phosphorylation of an $\mathrm{N}$-terminal serine (Ser 9), leading to the accumulation of $\beta$-catenin protein and promoted its nuclear translocation, where it activated transcription of target genes. ${ }^{36,37}$ In the present study, leptin has been shown to stimulate the phosphorylation of p44/42MAPK in A10 cells. Although we have no direct evidence of the modulation of leptin on the expression of $\beta$-catenin via $\mathrm{p} 44 / 42 \mathrm{MAPK}$, it had shown that leptin-induced phosphorylatioin of GSK-3 $\beta$ at Ser 9 and subsequent stabilization of $\beta$-catenin was mediated by p44/42MAPK in hepatic stellate cells. ${ }^{38}$ Further studies are required to clarify the mechanism of leptin on the $\beta$-catenin expression in vascular smooth muscle cells.

It was reported that leptin increased neointimal hyperplasia after vascular injury in mice. ${ }^{39}$ When injury occurs, vascular smooth muscle cells migrate from the tunica media to the intima, which leads to neointima formation. The present study indicated that FAEE significantly inhibited leptin-induced cells migration (Figure 6a). Vascular smooth muscle cells migration required the breakdown of the extracellular matrix. One possible mechanism by which vascular smooth muscle cells break down the extracellular matrix is by secreting MMPs. Previous study had reported that MMP-9 was important for the migration of vascular smooth muscle cells. ${ }^{40}$ Leptin has been shown to upregulate MMPs via p44/42MAPK signaling. ${ }^{41}$ In this study, leptin increased MMP-9 protein expression and activity, whereas FAEE attenuated this effect (Figures 6b and c). Although these results do not present a direct correlation between the increased MMP-9 protein levels, the increased MMP-9 activities and the change in migration properties, previous reports from other groups, MMP-9 can be activated by reactive oxygen species, and their expression appears to be regulated by oxidative stress. ${ }^{42}$ We assume that FAEE inhibited leptin-induced cell migration by attenuating MMP-9 activities. In support of this hypothesis, it has been shown that leptininduced intracellular reactive oxygen species production in human vascular smooth muscle cells. ${ }^{41}$ However, further studies are needed to determine whether or not the inhibitory 
effect of FAEE on A10 cell migration is due to MMPs downregulation.

Several studies have indicated that reactive oxygen species and MAPK are involved in vascular remodeling under various pathological conditions. ${ }^{43}$ Reactive oxygen species generation has been shown to be related to the activation of MAPK, which are key transducers of extracellular signals that promote cellular growth and movement. ${ }^{43,44}$ Leptin induced intracellular reactive oxygen species production in human vascular smooth muscle cells and that antioxidant inhibited the proliferative effect of leptin on these cells. ${ }^{41}$ This evidence supported the possibility that reactive oxygen species may act as second messengers in leptin-induced smooth muscle cell proliferation. ${ }^{45}$ Previous studies had demonstrated that FAEE had antioxidant properties. ${ }^{10,12}$ Meanwhile, $N$-acetylcysteine (reactive oxygen specie scavenger) mimicked the effects of FAEE that inhibiting the cell proliferation induced by leptin (Figure 1e). These results together with our observations that it does not rule out the possibility that antioxidant effect of FAEE may be related to inhibit the effect of leptin on smooth muscle cell growth. In addition, this study demonstrated MAPK as the regulator through which FAEE exerted its antiproliferation and antimigration effects, it is not possible to rule out other regulators involved in the proliferation and migration of vascular smooth muscle cells, such as nuclear factor- $\mathrm{kB},{ }^{41}$ heme oxygenase- $1 .^{13,46}$ Further studies are needed to clarify the relationship of reactive oxygen species and the antiatherogenic effect of FAEE.

Previous study had shown that FA exhibited antiproliferative effects on angiotensin II-stimulated vascular smooth muscle cells. ${ }^{47}$ In another study, however, FA was shown to enhance proliferation of MCF7 and BT20 human breast cancer cells as well as neural progenitor cell in vivo and in vitro, ${ }^{48,49}$ indicating the possibility that FA might exhibit different biological effects depending on cell types it interacts with. Like FA, FAEE has also been shown to exhibit the antioxidant effects in vitro. ${ }^{13}$ Studies in melanocytes and neuronal cells have shown that FAEE has a cytoprotective function related to its ability to induce the vitagene family such as heme oxygenase- 1 and heat shock protein $70 .{ }^{50-53}$ However, the antioxidant activity of identified FAEE in vascular smooth muscle cell model and in vivo has not yet to be reported. To our best knowledge, this is the first research demonstration that FAEE attenuated the proliferation and migration of vascular smooth muscle cells induced by leptin. These results may illustrate a potential clinical application for FAEE in vascular diseases. Regarding possible future in vivo applications, the different effects on cell types other than vascular smooth muscle cells cannot be excluded and that the relevance of the tested dosage for in vivo applications is unknown. Thus, many more detailed studies remain to be carried out before FAEE can be recommended in the treatment of vascular diseases.

In conclusion, the present study demonstrated that FAEE exerted multiple effects against the proliferation and migration of A10 cells induced by leptin in association with the downregulation of $\mathrm{p} 44 / 42 \mathrm{MAPK}$ activation and the expression of $\beta$-catenin, cyclin D1, p21 and MMP-9 protein and the upregulation of $\mathrm{p} 27$. This beneficial property of FAEE may make it a potential candidate for preventing or treating vascular diseases after obesity.

\section{CONFLICT OF INTEREST}

The authors declare no conflict of interest.

\section{ACKNOWLEDGEMENTS}

This work was supported in part by a research grant from the Ministry of Science and Technology (MOST-102-2320-B-016-021) and the Chi-Mei Medical Center (CMNDMC10310), Taiwan.

1 Ross R. Atherosclerosis-an inflammatory disease. N Engl J Med 1999; 340: 115-126.

2 Berg $\mathrm{AH}$, Scherer PE. Adipose tissue, inflammation, and cardiovascular disease. Circ Res 2005; 96: 939-949.

3 Sharma AM. Obesity and cardiovascular risk. Growth Horm IGF Res 2003; 13: S10-S17.

4 Friedman JM, Halaas JL. Leptin and the regulation of body weight in mammals. Nature 1998; 395: 763-770.

5 Fortu no A, Rodr’ıguez A, G’omez-Ambrosi J, Fr̈uhbeck G, D’ez J. Adipose tissue as an endocrine organ: role of leptin and adiponectin in the pathogenesis of cardiovascular diseases. J Physiol Biochem 2003; 59: 51-60.

6 Beltowski J. Leptin and atherosclerosis. Atherosclerosis 2006; 189 47-60.

7 Wallace AM, McMahon AD, Packard CJ, Kelly A, Shepherd J, Gaw A et al. Plasma leptin and the risk of cardiovascular disease in the west of Scotland coronary prevention study (WOSCOPS). Circulation 2001; 104 3052-3056.

8 Wolk R, Berger P, Lennon RJ, Brilakis ES, Johnson BD, Somers VK. Plasma leptin and prognosis in patients with established coronary atherosclerosis. $J$ Am Coll Cardiol 2004; 44: 1819-1824.

9 Bodary PF, Shen Y, Ohman M, Bahrou KL, Vargas FB, Cudney SS et al. Leptin regulates neointima formation after arterial injury through mechanisms independent of blood pressure and the leptin receptor/STAT3 signaling pathways involved in energy balance. Arterioscler Thromb Vasc Biol 2007; 27: 70-76.

10 Kanski J, Aksenova M, Stoyanova A, Butterfield DA. Ferulic acid antioxidant protection against hydroxyl and peroxyl radical oxidation in synaptosomal and neuronal cell culture systems in vitro: structure-activity studies. J Nutr Biochem 2002; 13: 273-281.

11 Kikuzaki H, Hisamoto M, Hirose K, Akiyama K, Taniguchi H. Antioxidant properties of ferulic acid and its related compounds. J Agric Food Chem 2002; 50: 2161-2168.

12 Ogiwara T, Satoh K, Kadoma Y, Murakami Y, Unten S, Atsumi T et al. Radical scavenging activity and cytotoxicity of ferulic acid. Anticancer Res 2004; 22: 2711-2717.

13 Scapagnini G, Butterfield DA, Colombrita C, Sultana R, Pascale A, Calabrese V. Ethyl ferulate, a lipophilic polyphenol, induces $\mathrm{HO}-1$ and protects rat neurons against oxidative stress. Antioxid Redox Signal 2004; 6: 811-818.

14 Yan JJ, Cho JY, Kim HS, Kim KL, Jung JS, Huh SO et al. Protection against beta-amyloid peptide toxicity in vivo with long-term administration of ferulic acid. Br J Pharmacol 2001; 133: 89-96.

15 Sasaki T, Maruyama H, Kase Y, Takeda S, Aburada M. Antianginal effects of lercanidipine on the vasopressin or methacholine induced anginal model in rats. Biol Pharm Bull 2005; 28: 811-816.

16 Park J, Ha H, Seo J, Kim MS, Kim HJ, Huh KH et al. Mycophenolic acid inhibits platelet-derived growth factor-induced reactive oxygen species and mitogenactivated protein kinase activation in rat vascular smooth muscle cells. Am J Transp/ 2004; 4: 1982-1990.

17 Morin PJ. Beta-catenin signaling and cancer. Bioessays 1999; 21: 1021-1030.

18 Considine RV, Sinha MK, Heiman ML, Kriauciunas A, Stephens TW, Nyce MR et al. Serum immunoreactive-leptin concentrations in normal weight and obese humans. N Engl J Med 1996; 334: 292-295. 
19 Minocci A, Savia G, Lucantoni R, Berselli ME, Tagliaferri M, Calò G et al. Leptin plasma concentrations are dependent on body fat distribution in obese patients. Int J Obes Relat Metab Disorders 2000; 24: 1139-1144.

20 Oda A, Taniguchi T, Yokoyama M. Leptin stimulates rat aortic smooth muscle cell proliferation and migration. Kobe J Med Sci 2001; 47: 141-150.

21 Schiafer K, Halle M, Goeschen C, Dellas C, Pynn M, Loskutoff DJ et al. Leptin promotes vascular remodeling and neointimal growth in mice. Arterioscler Thromb Vasc Biol 2004; 24: 112-117.

22 Zou Y, Hu Y, Melzlcr B, Xu Q. Signal transduction in arteriosclerosis: mechanical stress-active MAP kinases in vascular smooth muscle cells. Int J Mol Med 1998; 1: 827-834.

23 Force T, Bonvemtre JV. Growth factors and mitogen-activated protein kinases. Hypertension 1998; 31: 152-161.

24 Hyang $F$, Xiong X, Wang H, You S, Zeng $H$. Leptin-induced vascular smooth muscle cell proliferation via regulating cell cycle, activating ERK1/2 and NF-kB. Acta Biochim Biophys Sin 2010; 42: 325-331.

25 Zhang Q, Sakamoto K, Wagner KU. D-type cyclins are important downstream effectors of cytokin signaling that regulate the proliferation of normal and neoplastic mammary epithelial cells. Mol Cell Endocrinol 2014; 382: 583-592.

26 Marra DE, Simoncini T, Liao JK. Inhibition of vascular smooth muscle cell proliferation by sodium salicylate mediated by upregulation of p21(waf1) and p27(kip1). Circulation 2000; 102: 2124-2130.

27 Sherr C, Roberts J. CDK inhibitors: positive and negative regulators of G1-phase progression. Genes Dev 1999; 13: 1501-1512.

28 Cheng M, Olivier P, Diehl J, Fero M, Roussel M, Roberts J et al. The p21 (Cip1) and p27(Kip1) CDK 'inhibitors' are essential activators of cyclin D-dependent kinases in murine fibroblasts. EMBO J 1999; 18: 1571-1583.

29 LaBaer J, Garrett M, Stevenson L, Slingerland J, Sandhu C, Chou H et al. New functional activities for the p21 family of CDK inhibitors. Genes Dev 1997; 11: 847-862.

30 Weiss R, Joo A, Randour C. p21(Waf1/Cip1) is an assembly factor required for platelet-derived growth factor-induced vascular smooth muscle cell proliferation. J Biol Chem 2000; 275: 10285-10290.

31 MacDonald BT, Tamai K, He X. Wnt/beta-catenin signaling: components, mechanisms, and diseases. Dev Cell 2009; 17: 9-26.

32 Uglow EB, Slater S, Sala-Newby GB, Aguilera-Garcia CM, Angelini GD, Newby $A C$ et al. Dismantling of cadherin-mediated cell-cell contacts modulates smooth muscle proliferation. Circ Res 2003; 92: 1314-1321.

33 Wang X, Xiao Y, Mou Y, Zhao Y, Blankesteijn M, Hall JL. A role for the b-catenin/T-cell factor signaling cascade in vascular remodeling. Circ Res 2002; 90: 340-347.

34 Shtutman M, Zhurinsky J, Simcha I, Albanese C, D'Amico M, Pestell $\mathrm{R}$ et al. The cyclin D1 gene is a target of the $\beta$-catenin/LEF-1 pathway. Proc Natl Acad Sci USA 1999; 96: 5522-5527.

35 Tetsu 0 , McCormick $F$. $\beta$-Catenin regulates expression of cyclin D1 in colon carcinoma cells. Nature 1999; 398: 422-426.

36 Caraci F, Gili E, Calafiore M, Failla M, La Rosa C, Crimi N et al. TGF-beta1 targets the GSK-3beta/beta-catenin pathway via ERK activation in the transition of human lung fibroblasts into myofibroblasts. Pharmacol Res 2008; 57: 274-282.

37 Rodionova E, Conzelmann M, Maraskovsky E, Hess M, Kirsch M, Giese T et al. GSK-3 mediates differentiation and activation of proinflammatory dendritic cells. Blood 2007; 109: 1584-1592.

38 Zhai X, Yan K, Fan J, Niu M, Zhou Q, Zhou Y et al. The $\beta$-catenin pathway contributes to the effects of leptin on SREBP-1c expression in rat hepatic stellate cells and liver fibrosis. Br J Pharmacol 2013; 169: 197-212.

39 Shan J, Nguyen TB, Totary-Jain H, Dansky H, Marx SO, Marks AR. Leptinenhaced neointimal hyperplasia is reduced by mTOR and PI3K inhibitors. Proc Natl Acad Sci USA 2008; 105: 19006-19011.

40 Johnson C, Galis ZS. Matrix metalloproteinase-2 and -9 differentially regulate smooth muscle cell migration and cell-mediated collagen organization. Arterioscler Thromb Vasc Biol 2004; 24: 54-60.
41 Li L, Mamputu JC, Wiernsperger N, Renier G. Signaling pathways involved in human vascular smooth muscle cell proliferation and matrix metalloproteinase-2 expression induced by leptin: Inhibitory effect of metformin. Diabetes 2005; 54: 2227-2234.

42 Jin UH, Suh SJ, Chang HW, Son JK, Lee SH, Son KH et al. Tanshinone IIA from Salvia miltiorrhiza BUNGE inhibits human aortic smooth muscle cell migration and MMP-9 activity through AKT signaling pathway. J Cell Biochem 2008; 104: 15-26.

43 Kyaw M, Yoshizumi M, Tsuchiya K, Izawa Y, Kanematsu Y, Tamaki T. Atheroprotective effects of antioxidants through inhibition of mitogenactivated protein kinases. Acta Pharmacol Sin 2004; 25: 977-985.

44 Han MJ, Kim BY, Yoon SO, Chung AS. Cell proliferation induced by reactive oxygen species is mediated via mitogen-activated protein kinase in Chinese hamster lung fibroblast (V79) cells. Mol Cells 2003; 15: 94-101.

45 Lo IC, Shih JM, Jiang MJ. Reactive oxygen species and ERK 1/2 mediate monocyte chemotactic protein-1-stimulated smooth muscle cell migration. J Biomed Sci 2005; 12: 377-388.

46 Calabrese V, Calafato S, Puleo E, Cornelius C, Sapienza M, Morganti P et al. Redox regulation of cellular stress response by ferulic acid ethyl ester in human dermal fibroblasts: role of vitagenes. Clin Dermatol 2008; 26 : 358-363.

47 Hou YZ, Yang J, Zhao GR, Yuan YJ. Ferulic acid inhibits vascular smooth muscle cell proliferation induced by angiotensin II. Eur J Pharmacol 2004; 499: 85-90.

48 Chang CJ, Chiu JH, Tseng LM, Chang CH, Chien TM, Wu CW et al. Modulation of HER2 expression by ferulic acid on human breast cancer MCF7 cells. Eur J Clin Invest 2006; 36: 588-596.

49 Yabe T, Hirahara H, Harada N, Ito N, Nagai T, Sanagi T et al. Ferulic acid induces neural progenitor cell proliferation in vitro and in vivo. Neuroscience 2010; 165: 515-524.

50 Di Domenico F, Perluigi M, Foppoli C, Blarzino C, Coccia R, De Marco F et al. Protective effect of ferulic acid ethyl ester against oxidative stress mediated by UVB irradiation in human epidermal melanocytes. Free Radic Res 2009; 43: 365-375.

51 Sultana R, Ravagna A, Mohmmad-Abdul H, Calabrese V, Butterfield DA. Ferulic acid ethyl ester protects neurons against amyloid beta-peptide (142)-induced oxidative stress and neurotoxicity: relationship to antioxidant activity. J Neurochem 2005; 92: 749-758.

52 Perluigi M, Joshi G, Sultana R, Calabrese V, De Marco C, Coccia R et al. In vivo protective effects of ferulic acid ethyl ester against amyloid-beta peptide 1-42-induced oxidative stress. J Neurosci Res 2006; 84: 418-426.

53 Joshi G, Perluigi M, Sultana R, Agrippino R, Calabrese V, Butterfield DA. In vivo protection of synaptosomes by ferulic acid ethyl ester (FAEE) from oxidative stress mediated by 2,2-azobis(2-amidino-propane)dihydrochloride (AAPH) or $\mathrm{Fe}(2+) / \mathrm{H}(2) \mathrm{O}(2)$ : insight into mechanisms of neuroprotection and relevance to oxidative stress-related neurodegenerative disorders. Neurochem Int 2006; 48: 318-327.

(c) (1) $(-)$ This work is licensed under a Creative Commons Attribution-NonCommercial-NoDerivs 4.0 International License. The images or other third party material in this article are included in the article's Creative Commons license, unless indicated otherwise in the credit line; if the material is not included under the Creative Commons license, users will need to obtain permission from the license holder to reproduce the material. To view a copy of this license, visit http://creativecommons.org/licenses/by-nc-nd/4.0/ 